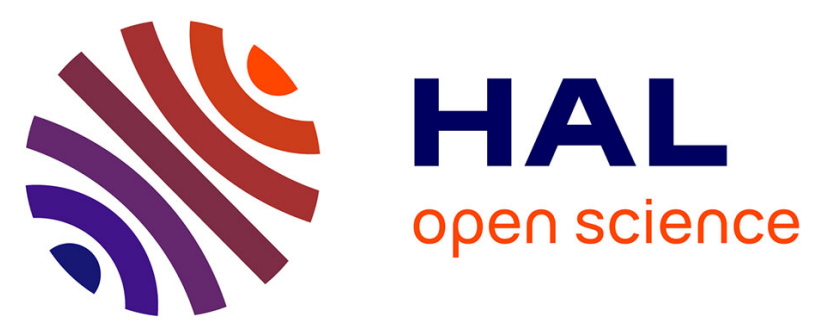

\title{
Heavy metal concentrations in dry and wet atmospheric deposits in Paris district: comparison with urban runoff
}

Stephane Garnaud, Jean-Marie Mouchel, Ghassan Chebbo, Daniel R.

Thevenot

\section{- To cite this version:}

Stephane Garnaud, Jean-Marie Mouchel, Ghassan Chebbo, Daniel R. Thevenot. Heavy metal concentrations in dry and wet atmospheric deposits in Paris district: comparison with urban runoff. Science of the Total Environment, 1999, 235, pp.235 - 245. 10.1016/S0048-9697(99)00199-0 . hal-01087668

\section{HAL Id: hal-01087668 \\ https://hal-enpc.archives-ouvertes.fr/hal-01087668}

Submitted on 26 Nov 2014

HAL is a multi-disciplinary open access archive for the deposit and dissemination of scientific research documents, whether they are published or not. The documents may come from teaching and research institutions in France or abroad, or from public or private research centers.
L'archive ouverte pluridisciplinaire HAL, est destinée au dépôt et à la diffusion de documents scientifiques de niveau recherche, publiés ou non, émanant des établissements d'enseignement et de recherche français ou étrangers, des laboratoires publics ou privés.

\section{(c)(1)}

Distributed under a Creative Commons Attribution| 4.0 International License 


\title{
Heavy metal concentrations in dry and wet atmospheric deposits in Paris district: comparison with urban runoff
}

\author{
Stéphane Garnaud, Jean-Marie Mouchel, Ghassan Chebbo, \\ Daniel R. Thévenot*
}

Cereve, Faculté de Sciences et Technologie, Université Paris XII-Val de Marne, 61 Avenue du Général de Gaulle, 94010

Créteil Cedex, France

\begin{abstract}
In urban areas, dry and wet atmospheric deposits are more rarely sampled than atmospheric particles. Nevertheless, fallout data are needed in order to compare concentrations and fluxes with street deposits and with samples collected during rain periods at roof outlets, gullies or within the sewer system. Such comparisons represent key issues in the understanding of micropollutant transport and evolution in urban areas. Within the Paris conurbation, four sites have been studied for dry, wet and total atmospheric deposits: Chatou, a suburb west of the Paris conurbation, Créteil, suburb, south-east, Fontainebleau at $48 \mathrm{~km}$ south-east from the centre of Paris, and 'Le Marais' within the centre of Paris. On each site, samples were continuously collected from 2 to 13 months. Comparison of median values of metal concentrations in various components of atmospheric fallout illustrates the influence of urban emissions: rainwater contamination with trace metals is only slightly larger in the centre of Paris than at Fontainebleau which illustrates the occurrence of medium range transport of atmospheric contamination. Focusing on an experimental urban catchment equipped with combined sewers, situated inside the 'Le Marais' district, within Paris, this paper compares metal concentrations of atmospheric deposits to dissolved and particulate ones in runoff from four roofs, three yards, six gullies, and at the catchment outlet. This comparison allows a better understanding of metal transport in urban areas and of the evolution of metal distribution between dissolved and particulate fractions. (c) 1999 Elsevier Science B.V. All rights reserved.
\end{abstract}

Keywords: Trace metals; Atmospheric deposit; Fallout; Rain; Dissolved/particulate partitioning; Urban catchment

\footnotetext{
* Corresponding author. Tel.: + 33-1-45171625; fax: +33-1-45171627.

E-mail address: thevenot@univ-paris12.fr (D.R. Thévenot)
} 


\section{Introduction}

In urban areas, many economic activities (transportation, domestic waste incineration, some industries...) generate atmospheric emission of mostly sub-micron particles. These very small particles may be transported over very long distances: the so-called remote pollution by urban areas has been studied over lakes or seas where it may figure as a major trace metal input to large aquatic ecosystems. Nevertheless, significant wet and dry fallout also occurs locally, and atmospheric fluxes onto impervious urban surfaces may significantly contribute to the contamination of urban runoff and play an important role in the urban cycle of metals, and further downstream on the contamination of receiving ecosystems.

Although metal contamination of urban aerosols is widely recognised, only a few studies have been devoted to the Paris conurbation. Most of them monitored metal concentration in aerosols (Juguet et al., 1984; Person et al., 1993) and few of them assessed total fallout (Grange and Deutsch, 1986; Granier, 1991).

This paper presents metal concentrations of atmospheric deposits collected at four sites inside the Paris conurbation, either in the suburb or the centre of the city. Dry and wet deposits have been measured. Because of collection problems, many sampling campaigns have focused on total deposition and wet deposition, dry deposition being computed as the difference (Granier, 1991). We argue that such an estimate may be poorly significant when the difference is small between total and wet fallout. The sampler we used is specially designed to avoid resuspension of deposited particles, and functions quite similarly to a total deposition sampler. In urban areas, because of street cleaning, dry and wet deposition may have significantly different fates inside the urban drainage system: it was therefore most important to assess both types of metal contamination with a similar accuracy.

Our major sampling site, in the centre of Paris, is situated within the 'Le Marais' experimental urban catchment: metal concentrations have been compared in rain, roof, yard and street runoff as well as in the catchment outlet within a combined sewer network (Gromaire-Mertz et al., 1999).

\section{Methodology}

\subsection{Sampling}

Four sampling sites have been selected to assess the spatial heterogeneity of wet and dry deposition in the Paris conurbation (Fig. 1). Chatou and Créteil stations are located in close suburbs, respectively, on the west and south-east of Paris city, Fontainebleau is approximately $48 \mathrm{~km}$ south-east, under frequent urban emission plumes (Table 1). The last site is located in the centre of Paris, within the 'Le Marais' experimental urban catchment (Gromaire-Mertz et al., 1998).

Dry and wet deposition samples have been separately collected at Chatou, Créteil and Paris (Table 1), using an ARS 1000 equipment (MTXItalia SPA, Modane, Italy). Both types of samples were collected in polyethylene cylinders $(29-\mathrm{cm}$ i.d.) covered with a single lid which automatically swaps from one container to the other, according to a rain probe. The container used for dry deposition was partially filled with approximately $1 \mathrm{~cm}$ high purity water in order to avoid resuspension of collected particles. Sampling duration for individual samples were adapted depending on the occurrence rainfall events, between 5 and 24 days.

Table 1

Sample collection for (W) wet, (D) dry or (T) total atmospheric deposits in Paris conurbation

\begin{tabular}{lllll}
\hline Site & Distance from Paris & Location & Sample period & Number (type) \\
\hline Chatou & $10 \mathrm{~km} \mathrm{~W}$ & Lawn & 14 February 1995-25 July 1995 & 8(W), 8(D) \\
Créteil & $5 \mathrm{~km} \mathrm{SE}$ & Roof (5th level) & 10 November 1994-17 January 1995 & 6(W), 6(D) \\
Paris & Centre & Roof (5th level) & 21 May 1996-23 April 1997 & 22(W), 28(D), 15(T) \\
Fontainebleau & $48 \mathrm{~km} \mathrm{SE}$ & Forest clearing & 18 Sepember 1996-21 May 1997 & 23(W) \\
\hline
\end{tabular}




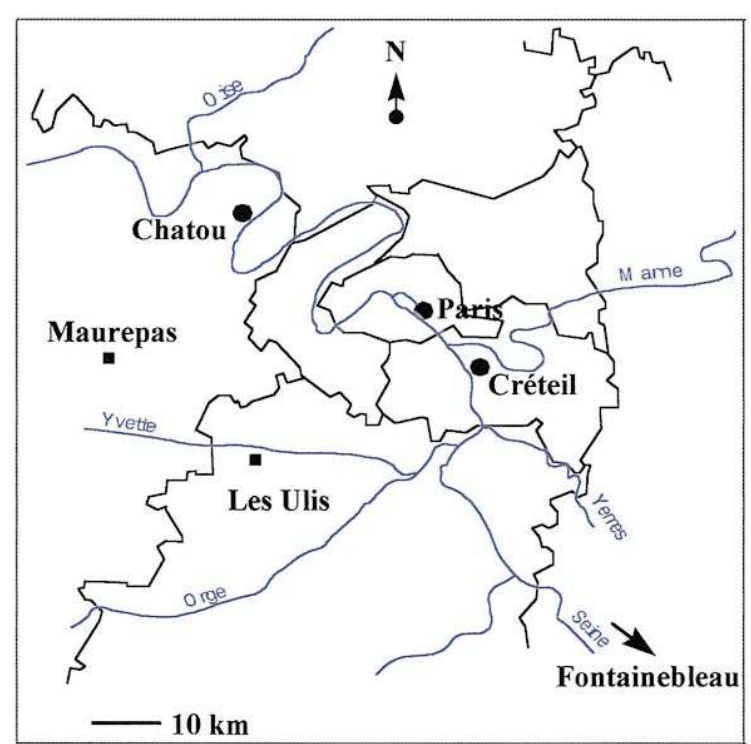

Fig. 1. Sampling sites for atmospheric deposits, both during this work (•) and previous ones ( $\bullet$ ) (Grange and Deutsch, 1986).

Trace metal distribution measured in rain samples after such time may not reflect the initial distribution during the event.

Sampling procedures for urban runoff within the 'Le Marais' experimental urban catchment have been previously described (Gromaire-Mertz et al., 1998, 1999): during individual rain events, bulk samples were collected within four gutter pipes (roof runoff), three yard drainage (yard runoff), six gullies (street runoff) and one combined sewer, at the catchment outlet.

\subsection{Sample treatment procedures}

After $\mathrm{pH}$ measurement in wet deposits, a 50-ml sub-sample was filtrated through a $0.45-\mu \mathrm{m}$ porosity membrane. The filtrate was acidified at $\mathrm{pH} 1$ with concentrated high purity nitric acid for dissolved metal determination. A second wet deposition sub-sample $(50 \mathrm{ml})$ was acidified at $\mathrm{pH} 1$ for bulk metal determination. Preliminary experiments have shown that digestion of bulk rain samples or total deposits, with concentrated perchloric and nitric acids, yields similar metal concentrations than $\mathrm{pH} 1$ acidification with nitric acid. The remaining rain water was filtrated through $0.7-\mu \mathrm{m}$ nominal porosity glass fibre membranes for suspended solid (SS) determination.

Two 20-ml sub-samples of the slurry containing dry deposits were further digested in PTFE beakers with $18 \mathrm{ml} 65 \%$ nitric acid and $2 \mathrm{ml} \mathrm{70 \%}$ perchloric acid (Merck, Suprapure) at $110^{\circ} \mathrm{C}$ on a sand bath. After complete evaporation, the remaining solids were dissolved into $30 \mathrm{ml} 1 \mathrm{M}$ nitric acid (Merck, Suprapure) for metal determination. Suspended solids were assessed on the remaining dry deposition sub-sample as indicated above.

Both dry and wet ARS 1000 containers were rinsed on site with $1110 \%$ nitric acid (Merck, Suprapure) to collect metals possibly adsorbed on container walls. Trace metal amounts in rinsing waters were included to provide dry (particulate) or wet (bulk) metal concentrations.

Table 2

Confidence intervals for the median (95\%) for ARS 1000 and rain gauge total metal deposition sampling at Paris, i.e. sum of dry and wet fallout, and for wet deposits at Chatou, Créteil, Paris and Fontainebleau $\left(\mu \mathrm{g}^{-1}\right)^{\mathrm{a}}$

\begin{tabular}{|c|c|c|c|c|c|c|}
\hline & \multicolumn{3}{|c|}{ Total deposits (dry and wet) } & \multicolumn{3}{|c|}{ Wet deposits (rain) } \\
\hline & \multicolumn{2}{|l|}{$\begin{array}{l}\text { Paris } \\
(1996-1997)\end{array}$} & \multirow{2}{*}{$\begin{array}{l}\text { Chatou } \\
(1995) \\
\text { ARS } 1000\end{array}$} & \multirow{2}{*}{$\begin{array}{l}\begin{array}{l}\text { Créteil } \\
(1994)\end{array} \\
\text { ARS } 1000\end{array}$} & \multirow{2}{*}{$\begin{array}{l}\text { Paris } \\
(1996-1997) \\
\text { ARS } 1000\end{array}$} & \multirow{2}{*}{$\begin{array}{l}\text { Fontainebleau } \\
(1996-1997) \\
\text { APS }\end{array}$} \\
\hline & ARS 1000 & Rain gauge & & & & \\
\hline $\mathrm{Cd}$ & $0.04-0.14$ & $0.14-0.27$ & $0.05-0.11$ & $0.10-0.33$ & $0.05-0.15$ & $0.86-2.0$ \\
\hline $\mathrm{Cu}$ & $2.1-4.0$ & $14.1-30.1$ & $1.2-3.2$ & $3.4-11.1$ & $3.0-6.6$ & $1.6-2.8$ \\
\hline $\mathrm{Pb}$ & $3.3-8.3$ & $22.9-73.6$ & $1.9-5.4$ & $3.7-14.9$ & $5.9-17.2$ & $1.9-4.9$ \\
\hline $\mathrm{Zn}$ & $11.9-26.8$ & $26.4-375$ & $9.2-64.3$ & $10.8-42.7$ & $12.1-30.1$ & $3.5-56$ \\
\hline
\end{tabular}

${ }^{\text {a }}$ Since most data distributions were far from normal, we used non parametric estimates for the median value to compute estimates around the median (Tomassone et al., 1993) 
In order to compare separate wet and dry deposition sampling with total deposition sampling, total deposits have also been collected at Paris centre using a rain gauge designed to assess rain depth. Total metal deposits were much larger in the rain gauge samples than in the ARS 1000, the larger difference being observed for lead and zinc (Table 2). A contamination likely occurred inside the rain gauge where rain water may be shortly in contact with the metallic pieces which enable the measurement of rainfall. Data obtained from this sampler were finally discarded.

At Fontainebleau site, wet deposits were collected weekly by 'Office National des Forêts' (ONF) using a device similar to the ARS 1000, i.e. the 'acid precipitation sampler' APS (Ecomesure, Bris sous Forges, France), installed in a forest clearing. The APS wet collector was not rinsed at each sampling period. These samples were shipped monthly to our laboratory and approximately 80-ml sub-samples were acidified at $\mathrm{pH} 1$ with concentrated nitric acid (Merck, Suprapure) for bulk metal determination.

Immediately after each rain event, urban runoff samples were filtrated and separate dissolved and bulk fractions were determined for metals, using procedures described above for wet and dry fallout, respectively, i.e. $\mathrm{pH} 1$ acidification of the dissolved fraction, and digestion with concentrated perchloric and nitric acids of the bulk samples. Preliminary experiments have shown that digestion with concentrated nitric and perchloric acids of bulk samples gives a metal amount close to the one obtained by adding separately determined dissolved and particulate concentrations.

All samples were stored in the dark at $4^{\circ} \mathrm{C}$ prior to analysis. Before use, all containers, including samplers, were soaked for $24 \mathrm{~h}$ in $2 \%$ detergent and $24 \mathrm{~h}$ in $10 \%$ nitric acid baths. They were thoroughly rinsed with ultrapure water before drying in a laminar flow hood, inside a class 1000 clean room. Blanks were realised on site, by collecting ultrapure water previously poured into the containers and sampled either immediately or after 1-week storage. Blanks were acidified with $1 \%$ high purity nitric acid and preserved until metal determination.

\subsection{Metal determination procedures}

Cadmium, copper, lead and zinc were determined by Atomic Absorption Spectroscopy either in air-acetylene flames or in electrothermic graphite furnaces depending on the metal concentration, sometimes with addition of a matrix modifier.

Particulate metal determination was validated using three certified samples: NIST 1648 and BCR $144 \mathrm{R}$ and $146 \mathrm{R}$ following the procedure described above for dry deposits. Except for cadmium in BCR $144 \mathrm{R}$ sample, which levels are very low, i.e. $1.5 \mathrm{mg} \mathrm{kg}^{-1}$ dry wt., deviations between measured and certified values were lower than $10 \%$. Standard deviations obtained on replicates of particulate standard were in the $2-9 \%$ range for all metals. Replicates between dry deposits samples could be much worse sometimes reaching a 50\% difference (average difference was $10 \%$ ). We suggest that the dispersion was related to a poor homogenisation of samples due to the presence of adhesive material, like soot, in the samples.

Dissolved metal determinations were also validated using three certified samples: NIST 1643c, SPS-WW1 and SPS-SW2. These samples were systematically used to control the validity of all calibration curves. Except for copper in the SPSSW2 sample, deviations between measured and certified values are lower than $5 \%$.

\section{Results and discussion}

\subsection{Validation of atmospheric fallout sampling procedures}

Concentrations measured in blanks collected either immediately or after 1-week storage in closed atmospheric deposit collectors were lower than $0.01,0.12$ and $0.20 \mu \mathrm{g} \mathrm{l}^{-1}$ (detection limits) for cadmium, copper and lead, respectively. Blanks for zinc were measurable $(0.25-0.30 \mu \mathrm{g}$ $1^{-1}$ ), but these values could be considered as negligible compared to the high amounts of zinc measured in dry and wet deposition samples.

Trace metals in the acidified water used for 
rinsing the containers could contain significant amounts of the dry and wet deposition: lowerupper decile range reach $0-12 \%$ of particulate $\mathrm{Cd}, 7-30 \%$ of $\mathrm{Cu}, 14-33 \%$ of $\mathrm{Pb}$, and $2-9 \%$ of $\mathrm{Zn}$ for 29 dry deposits samples; $0 \%$ of bulk $\mathrm{Cd}$, $0-62 \%$ of $\mathrm{Cu}, 15-66 \%$ of $\mathrm{Pb}$ and $0-14 \%$ of $\mathrm{Zn}$ for 22 wet deposits samples. The amounts of recovered metals during this rinsing procedure were higher in samples with higher SS contents. Thus rinsing the container wall is a most important step inside the overall procedure.

\subsection{Wet deposits}

\subsubsection{Bulk metal concentrations in rain}

Most successive rain events collected during the 2-13-month sampling periods at Chatou, Créteil, Fontainebleau and Paris had usual rain depths $(2.0-27.2 \mathrm{~mm})$ with a return period lower than 1 year, except one strong event in Paris (August 1996) (return period approx. 2 years). Bulk metal concentrations, i.e. taking into account dissolved and particulate fractions of rain samples, show a large temporal variability as previously observed in other urban areas (Galloway et al., 1982; Dannecker et al., 1990; Van Daalen, 1991).

Taking into account the strong variability of concentrations inside one single data set, bulk metal concentrations were not significantly different at Chatou and Créteil during the 1994-1995 campaigns, and at Paris and
Fontainebleau during 1996-1997 (Table 2). As sampling periods were different for Chatou, Créteil and Paris, it is difficult to make a valid comparison between these three sites and precisely assess the space heterogeneity of rain contamination within the Paris conurbation. However, since sampling periods were almost identical at Paris and Fontainebleau, our results show that, except for cadmium, only a weak difference appears between bulk metal concentrations within rain samples collected on both of these sites, although approximately $48 \mathrm{~km}$ apart. Within the four studied metals copper and lead levels are significantly lower at Fontainebleau. Dominating winds in this area are eastward with moderate speeds of approximately 2-4 $\mathrm{m} \mathrm{s}^{-1}$ (data from Météo-France, 1986-1996). Since wind is a most important factor in the dispersion and transport of atmospheric pollution (Galloway et al., 1982), it is likely that the Fontainebleau station may be under the influence of the Paris conurbation, as already shown for atmospheric gaseous pollutants (Ulrich and Williot, 1993). We have no explanation with regards to the higher concentrations of cadmium recorded in rain water at Fontainebleau: further field inquiries are necessary in order to locate a local contamination source or to identify a sampling problem.

Comparisons of the mean metal concentration with literature values shows that contamination of rain, within the Paris conurbation, is somewhat smaller than in other urban sites, especially for

Table 3

Mean bulk metal concentrations in rain water $\left(\mu \mathrm{g}^{-1}\right)$

\begin{tabular}{|c|c|c|c|c|c|}
\hline Site & $\mathrm{Cd}$ & $\mathrm{Cu}$ & $\mathrm{Pb}$ & $\mathrm{Zn}$ & Reference (year) \\
\hline Urban sites & $0.5-19$ & $6.4-120$ & $4.1-190$ & $6-280$ & $\left(\right.$ Galloway et al., 1982) ${ }^{\mathrm{a}}$ \\
\hline Industrial & 0.7 & 34.4 & 21.1 & 234.6 & (Dannecker et al., 1990) \\
\hline Paris conurbation & & & & & (Grange and Deutsch, 1986) \\
\hline Maurepas & 0.7 & 4.5 & 7.9 & 21.9 & \\
\hline Les Ulis & 1.1 & 3.8 & 8.7 & 51.1 & \\
\hline Paris centre & 2.4 & - & 60 & 140 & (Granier, 1991) \\
\hline Urban (Netherlands) & 0.9 & 8 & 20 & 31 & (Van Daalen, 1991) \\
\hline Chatou & 0.09 & 3.0 & 13.5 & 34.1 & This work (1995) \\
\hline Créteil & 0.26 & 7.2 & 10.5 & 29.8 & (1994) \\
\hline Paris centre & 0.11 & 6.0 & 13.7 & 38.8 & $(1996-1997)$ \\
\hline Fontainebleau & 1.7 & 2.2 & 2.5 & 40 & (1996-1997) \\
\hline
\end{tabular}

\footnotetext{
${ }^{\mathrm{a}}$ Range of mean values collected from a literature review (1975-1982).
} 
cadmium and copper (Table 3). Data obtained more than 10 years ago inside the Paris conurbation, i.e. at Maurepas and Les Ulis, were 3-10 times more contaminated in cadmium (Grange and Deutsch, 1986), while copper, zinc or lead values were slightly lower, the evolution being not really significant. This cadmium level decrease could evidence efforts in better treatment of urban atmospheric emissions, including waste incineration fumes which are considered as a major source of metal in the atmosphere (Fahrni, 1991). A significant decrease of cadmium contamination has also been observed in the River Seine suspended solids downstream of Paris, from 1991 to 1994 (Estèbe, 1996). In the River Seine, every year, the higher cadmium concentrations in suspended solids were always observed during the low flow period (generally from June to September): they reached $8 \pm 1.5 \mathrm{mg} \mathrm{kg}^{-1}$ dry wt. in summer 1991 and decreased down to approximately $3 \mathrm{mg} \mathrm{kg}^{-1}$ dry wt. during summer 1994.

As previously observed (Owe et al., 1982), we were unable to demonstrate any significant correlation between bulk metal concentrations in rain and the duration of dry weather before the storm event or $\mathrm{pH}$, or rain parameters such as total rainfall depth or duration. Except few rain events with the highest zinc concentrations (larger than $80 \mu \mathrm{g}^{-1}$ ), bulk metal concentrations appear to be correlated ( $r^{2}$ values reach $0.40,0.43$ and 0.54 for $\mathrm{Cd}, \mathrm{Cu}$ and $\mathrm{Pb}$ vs. $\mathrm{Zn}$, respectively) (Fig. 2). $\mathrm{Pb} / \mathrm{Zn}, \mathrm{Cu} / \mathrm{Zn}$ and $\mathrm{Cd} / \mathrm{Zn}$ bulk concentrations ratios reach, on average, $0.36,0.20$ and 0.0055 , respectively. These ratios are close to those previously observed in aerosols collected within tunnels of the circular Paris highway for copper and cadmium, namely 0.18 and 0.011 , but somewhat smaller than those for lead, i.e. 2.0 (Lebreton and

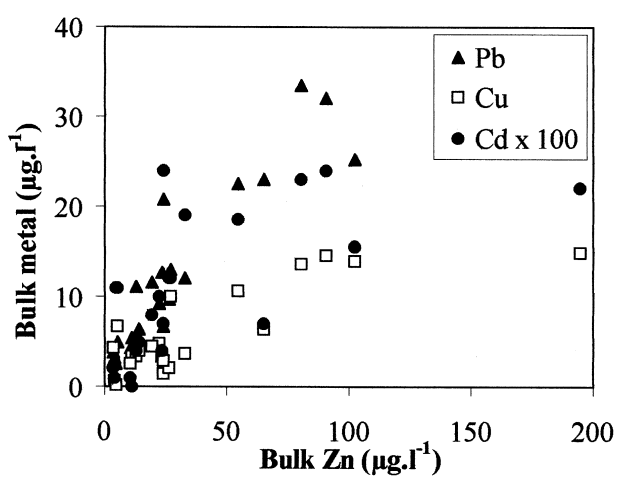

Fig. 2. Correlation between bulk metal concentrations in rain at Paris.

Thévenot, 1992), which may be related to the extended use of unleaded gasoline in France in May 1989 when these aerosols were collected (Table 5). This similitude suggests a common origin of these metals found either in urban aerosols and in urban rain water.

\subsubsection{Dissolved-particulate metal distribution in rain water}

Distribution of metal in dissolved and particulate fractions is an essential factor for the assessment of metal transport by rain and urban runoff (Losno et al., 1993). Metals were mostly found in the dissolved fraction in Paris wet fallout, although dissolved/total ratio were quite variable (Table 4). Similar results have been observed in most urban (Pattenden et al., 1982) and rural or remote sites (Martin et al., 1989; Chester et al., 1994). This high dissolved metal fraction is related to the lower $\mathrm{pH}$ of rain water in urban areas and to lower SS values compared to runoff or river water where most metals are generally bound to particulate matter as well as to rain water

Table 4

Dissolved metal distribution in rain water: lower-upper decile range of dissolved/total metal ratio (\%)

\begin{tabular}{lrrrrl}
\hline Site & \multicolumn{1}{c}{$\mathrm{Cd}$} & $\mathrm{Cu}$ & $\mathrm{Pb}$ & $\mathrm{Zn}$ & Reference \\
\hline Urban (England) & 80 & 96 & 93 & 97 & (Pattenden et al., 1982) \\
Paris & $75-100$ & $57-100$ & $63-90$ & $84-100$ & This work \\
Rural (France) & 98 & 43 & 86 & - & (Martin et al., 1989) \\
Rural (North Sea) & - & $19-60$ & $62-81$ & $53-87$ & (Chester et al., 1994) \\
\hline
\end{tabular}


samples collected during Sahara dust events (red rains) where $\mathrm{pH}$ and $\mathrm{SS}$ content simultaneously increase (Loye-Pilot and Morelli, 1988; Guieu, 1991). In our data set, at Paris centre station, median values of $\mathrm{pH}$ and SS were 4.5 and $0.2 \mathrm{mg}$ $1^{-1}$, respectively.

Fig. 3 shows that, for all four studied metals, the distribution factors $K_{D}$, i.e. the ratio between particulate $\left(\mu \mathrm{g} \mathrm{kg}^{-1}\right)$ and dissolved metal concentrations $\left(\mu \mathrm{g}^{-1}\right)$, are larger for low SS levels in rain water. The measurement of low SS levels in such small rain volumes is quite delicate and might lead to over-estimated $K_{D}$ values. Besides such possible experimental artefacts, a possible hypothesis could be, for low SS values, a higher contamination of aerosols. Larger SS values would be due a dilution of highly contaminated, typically urban, aerosols with less contaminated ones.

\subsubsection{Comparison of metal distribution in rain water and in urban runoff}

Metal particulate fractions severely increased following the way down of water from rain to the outlet of urban catchment or receiving aquatic ecosystems in urban areas. Indeed, following the dramatic increase of $\mathrm{SS}$ as well as $\mathrm{pH}$, which mean values reached 4.5 in rain and 6.4, 7.0, 6.8

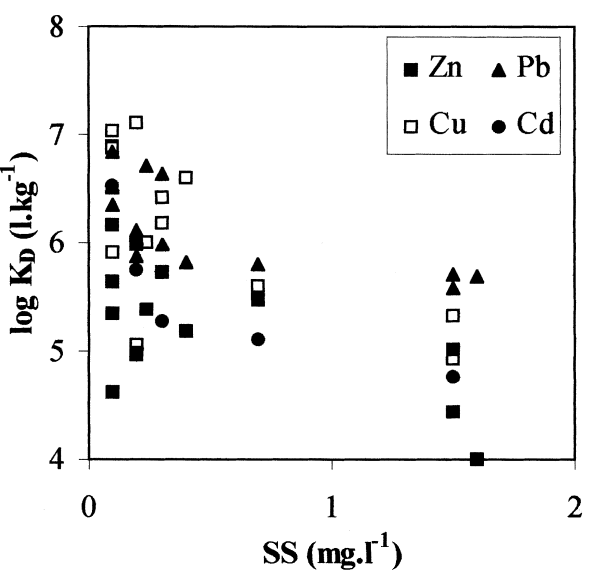

Fig. 3. Correlation between the logarithm of metal distribution factor $K_{D}\left(1 \mathrm{~kg}^{-1}\right)$ and the SS level $\left(\mathrm{mg} \mathrm{l}^{-1}\right)$ in rain samples at Paris centre.

and 7.0 in roof, yard and street runoff, as well as in combined sewer (average of 20 rain events), particulate cadmium fraction increased very significantly. Whereas mostly dissolved in rain samples, cadmium and zinc became mostly particulate in yard, street and catchment outlet samples. A similar evolution of particulate metal ratio was observed for all metals (Fig. 4). Roof runoff sam-

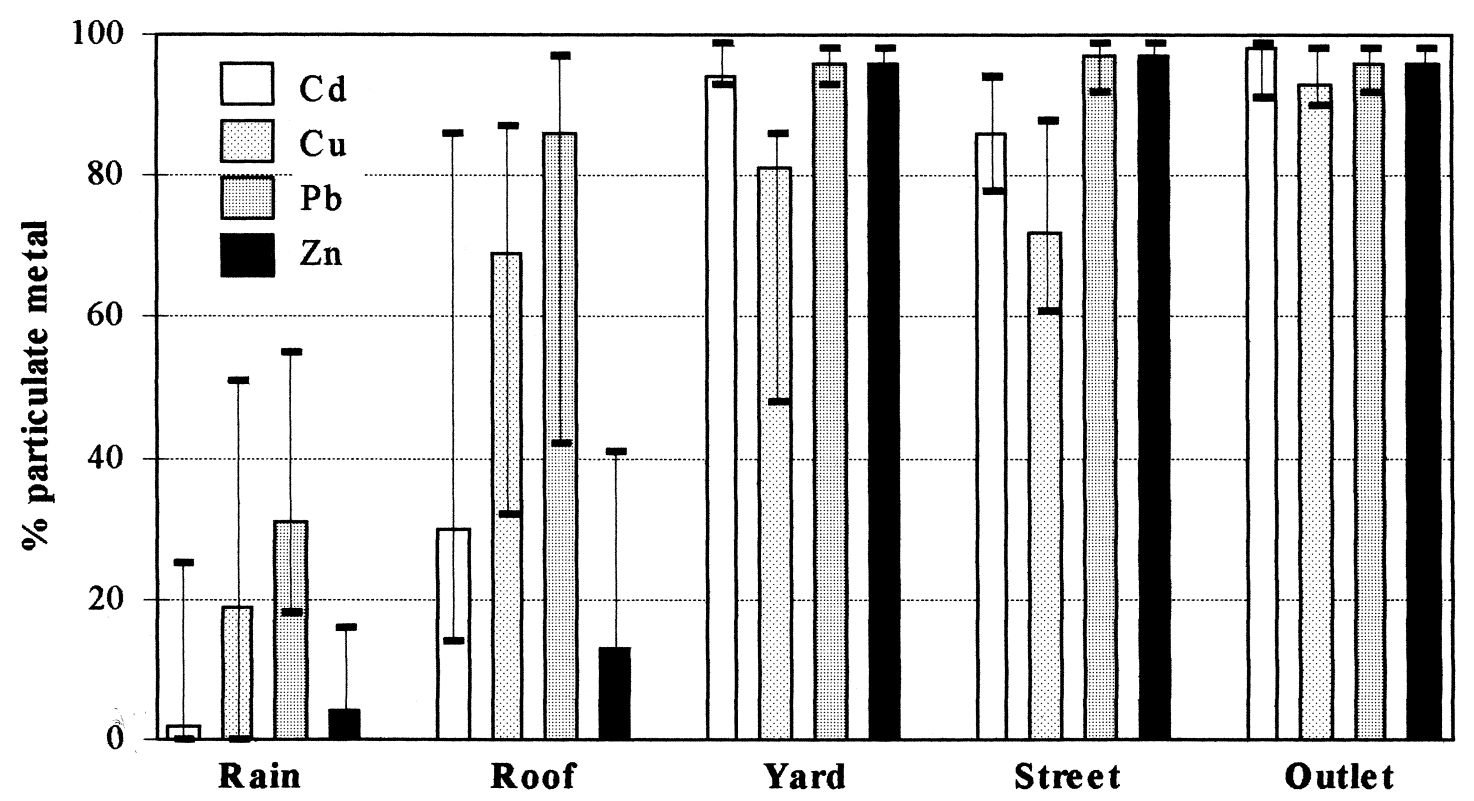

Fig. 4. Comparison of particulate metal ratio at all sites of the 'Le Marais' experimental urban catchment (median values). 
ples were somewhat different since they presented a very large heterogeneity in metal distribution, related to the nature of the roof material (Gromaire-Mertz et al., 1999). Cadmium and zinc remained dissolved in roof outlet samples, while copper and lead became mostly particulate at these sites. Comparison of rain and roof runoff particulate metal distribution shows that chemical properties of metals play an important role in their transport mechanism and that urban surfaces modify very significantly their distribution.

\subsection{Dry deposits}

Although mostly dissolved in wet deposits, the particulate fraction of metals is of great importance since it allows a comparison between dry and wet deposits as well as between dry deposits and urban aerosols. Particulate metal concentrations were not significantly different in dry and wet fallout samples collected at Paris centre (Table 5). Copper and zinc levels were somewhat higher than values previously obtained in aerosols collected within Paris circular highway (Lebreton and Thévenot, 1992): these two metals are probably, within Paris centre, issued from urban material corrosion.

Like bulk metal concentrations in rain water, particulate ones were not correlated with dry weather duration; neither were they correlated with the amount of collected particles. Particulate cadmium and zinc in wet deposits presented a correlation $\left(r^{2}=0.69, n=28\right)$ which may illustrate their common source. These two elements are often associated in zinc metallurgy (Pacyna,
1984), urban waste incineration (Greenberg et al., 1978; Fahrni, 1991) or car by-products (Granier, 1991).

Taking into account respective amounts of particulate metals in dry and wet fallout, it was possible to compare each source within total particulate deposits (Fig. 5). The wet/total particulate metal ratio was highly variable, approximately $20-60 \%$. Thus particulate metals were issued, in equivalent amounts, from both types of deposits. Within such variability, sources for particulate metal appear to be larger for zinc in dry deposits and for lead in wet ones.

\subsection{Bulk metal concentration evolution within an urban catchment}

SS levels increased by almost two decades from rain water to roof runoff $\left(0.1-1.6 \mathrm{mg} \mathrm{l}^{-1}\right)$ and further increased in roof, yard and street runoff, the largest values being observed at the catchment outlet $\left(180 \mathrm{mg} \mathrm{l}^{-1}\right)$. Bulk metal concentrations presented large temporal variability at all sites of the experimental catchment. For example cadmium level varied over more than a decade, both in rain and roof runoff samples. If bulk cadmium concentration was not significantly different at all runoff sites and at the catchment outlet, its level in rain samples was almost a decade lower. This illustrates the important role of urban runoff contamination by dry atmospheric fallout and other local sources. Such bulk metal enrichment of urban runoff, from rain to catchment outlet was not specific to cadmium but was observed for all studied metals (Fig. 6): the

Table 5

Particulate metal concentrations in highway aerosols and dry/wet fallout at Paris $\left(\mathrm{mg} \mathrm{kg}^{-1} \mathrm{dry}\right.$ wt.): lower-upper decile range (number of samples)

\begin{tabular}{|c|c|c|c|c|c|}
\hline Sample type (period) & $\mathrm{Cd}$ & $\mathrm{Cu}$ & $\mathrm{Pb}$ & $\mathrm{Zn}$ & Reference \\
\hline $\begin{array}{l}\text { Highway aerosols } \\
\text { (May 1989) }\end{array}$ & 26.6 & 435 & 4800 & 2330 & (Lebreton and Thévenot, 1992) \\
\hline $\begin{array}{l}\text { Dry fallout } \\
(1996-1997)\end{array}$ & $\begin{array}{r}11-67 \\
(n=28)\end{array}$ & $\begin{array}{r}800-2900 \\
(n=28)\end{array}$ & $\begin{array}{r}2500-14400 \\
(n=28)\end{array}$ & $\begin{array}{r}3300-24800 \\
(n=28)\end{array}$ & This work \\
\hline $\begin{array}{l}\text { Wet fallout } \\
(1996-1997)\end{array}$ & $\begin{array}{l}10-100 \\
(n=6)\end{array}$ & $\begin{array}{r}200-9300 \\
(n=14)\end{array}$ & $\begin{array}{r}1100-17000 \\
(n=15)\end{array}$ & $\begin{array}{r}300-16600 \\
\quad(n=14)\end{array}$ & This work \\
\hline
\end{tabular}




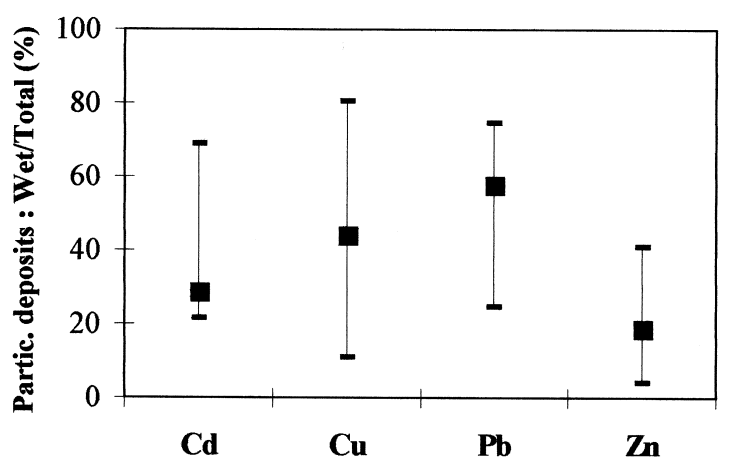

Fig. 5. Particulate metals issued from wet deposit within total atmospheric fallout: median and decile values $(n=22)$.

increase factor in metal concentration, from rain to urban runoff and catchment outlet, reached 12 , 30, 30 and 60 for cadmium, copper, lead and zinc, respectively. Besides the dry or wet atmospheric fallout seen above, corrosion of roof and urban surfaces as well as human activities contributes to this contamination: corrosion or emission from vehicles, commercial activities... Bulk metal concentrations were similar within all urban runoff samples except for zinc and lead which were particularly concentrated in roof runoff samples, due to their contamination by corrosion of roof materials of this historical district of Paris centre. At all sites it appeared that bulk metal concentrations may be ranked as:

$\mathrm{Cd} \ll \mathrm{Cu}<\mathrm{Pb} \ll \mathrm{Zn}$

\section{Conclusion}

This work shows the importance of atmospheric water or particle samples within an urban area. Data obtained on air samples do not allow a direct comparison with urban runoff. On the contrary, separate sampling of dry and wet deposits, although more difficult to achieve since they require permanent location for equipment such as ARS 1000, allows such a comparison. Sampling of atmospheric deposit further requires a well controlled procedure including extensive cleaning of containers before use, thorough rinsing after use and blanks quality control.

Comparison of metal contamination of wet fallout sampled simultaneously at the Paris centre

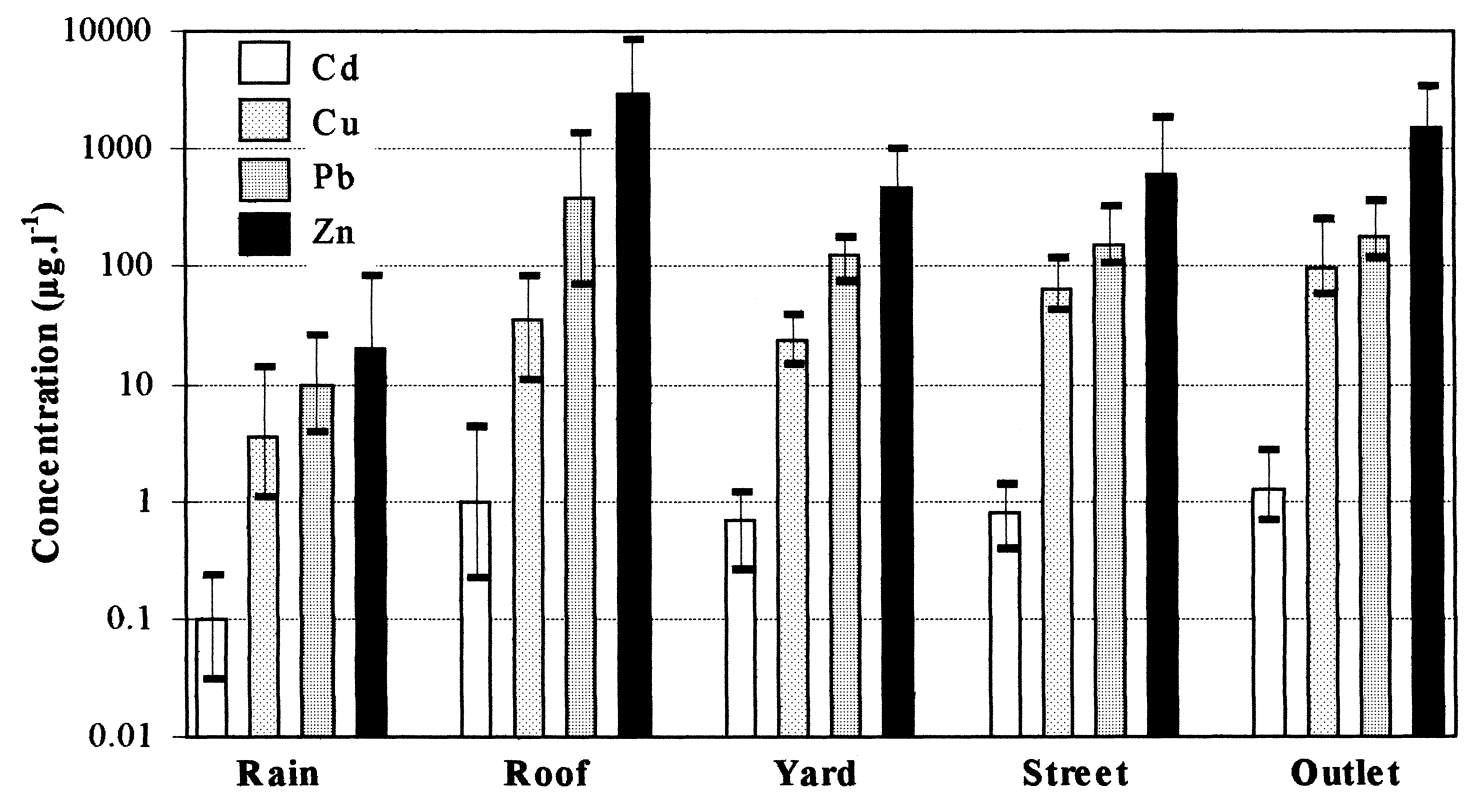

Fig. 6. Comparison of metal bulk concentrations at all sites of the 'Le Marais' experimental urban catchment (median values). 
and at $48 \mathrm{~km}$ apart shows that their levels were only significantly lower for copper and lead. This demonstrates the importance of urban plumes of atmospheric pollution. Although these bulk metal levels were not higher than in other urban sites, they present a major concern for the environment: metals are almost entirely dissolved and, consequently, under bioavailable and toxic forms.

During their transport and runoff on various urban surfaces, wet atmospheric deposits undergo very strong evolutions. This SS level increase was followed by an increase in particulate metal distribution factor and a decrease in metal mobility and bioavailability. Ongoing experiments show that this evolution continues within the sewer itself and that particulate metal mobility, as assessed by geochemical speciation, decreases from street deposits to gully samples and from them to the sewer outlet. This evolution is to be taken into account in the design of urban runoff treatment techniques as well as in the management of solid waste issued from such treatments.

\section{Acknowledgements}

Authors acknowledge the support of PIRENSeine (CNRS GDR 1067) and 'Le Marais' Experimental Urban Catchment programmes, as well as the collection of rain fallout samples at Fontainebleau by 'Office National des Forêts' and Météo-France for meteorological data.

\section{References}

Chester R, Bradshaw GF, Corcoran PA. Trace metal chemistry of the North Sea particulate aerosol concentrations, sources and sea water fates. Atmos Environ 1994;28 (17):2873-2883.

Dannecker W, Au M, Stechmann H. Substance load in rainwater runoff from different streets in Hamburg. Sci Total Environ 1990;93:385-392.

Estèbe A. Impact de l'agglomération Parisienne et de ses rejets de temps de pluie sur les concentrations en métaux des matières en suspension et des sédiments en Seine en période estivale. PhD thesis, University Paris XII, France, 1996:244.

Fahrni HP. Usines d'incinération des ordures ménagères et pollution atmosphérique: bilan actuel. Pollut Atmos, Avril-Juin 1991:247-251.

Galloway JN, Thornton JD, Norton SA, Volchok HL, Mc Lean RAN. Trace metals in atmospheric deposition: a review and assessment. Atmos Environ 1982;16(7): 1677-1700.

Grange D, Deutsch J-C. Qualité des eaux de pluie: comparaison des flux polluants avant et après ruissellement. Société Hydrotechnique de France, XIXth Hydraulic Meetings, Human activities impact on the continental waters, Question II, 1986:2.1-2.5.

Granier L. Apports atmosphériques en organochlorés à l'hydrosphère: comparaison avec les métaux lourds. $\mathrm{PhD}$ thesis, University Paris 6, 1991:160.

Greenberg RR, Gordon GE, Zoller WH, Jacko RB, Neuendorf DW, Yost KJ. Composition of particles emitted from the Nicosia Municipal Incinerator. Environ Sci Technol 1978;12:1329-1332.

Gromaire-Mertz M-C, Chebbo G, Saad M. Origins and characteristics of urban wet weather pollution in combined sewer systems: the experimental urban catchment 'Le Marais' in Paris. Water Sci Technol 1998;37(1):35-43.

Gromaire-Mertz M-C, Garnaud S, Gonzalez A, Chebbo G. Characterisation of urban runoff pollution in Paris. Water Sci Technol 1999;39(2):1-8.

Guieu C. Apports atmosphériques à la Méditerranée NordOccidentale. $\mathrm{PhD}$ thesis, University Paris 6, France, 1991:225.

Juguet B, Coviaux F, Le Moullec Y, Festy B. Etude de la fraction minérale de l'aérosol urbain à Paris-Bilan d'une surveillance prolongée. Pollut Atmos Janvier-Mars 1984:3-12.

Lebreton L, Thévenot DR. Metal pollution released by road aerosols. Environ Technol 1992;13:35-44.

Losno R, Colin JL, Le Bris N, Bergametti G, Jickells T, Lim B. Aluminium solubility in rainwater and molten snow. $\mathbf{J}$ Atmos Chem 1993;17:29-43.

Loye-Pilot M-D, Morelli J. Fluctuations of ionic composition of precipitations collected in Corsica related to changes in the origins of incoming aerosols. J Aerosol Sci 1988; 19(5):577-585.

Martin JM, Elbaz-Poulichet F, Guieu C, Loye-Pilot M-D, Han G. River vs. atmospheric input of material to the Mediterranean Sea: an overview. Mar Chem 1989;28:159-182.

Owe M, Craul J, Halverson HG. Contaminant levels in precipitation and urban surface runoff. Water Resour Bull 1982; 18(5):863-868.

Pacyna JM. Estimation of the atmospheric emissions of trace elements from anthropogenic sources in Europe. Atmos Environ 1984;18(1):41-50.

Pattenden NJ, Branson JR, Fisher EMR. Trace elements measurements in wet and dry deposition and airborne particulate at an urban site. In: Georgii H-W, Pankrath J, editors. Deposition of atmospheric pollutants, 1982: 173-184. 
Person A, Petit-Coviaux F, Le Moullec Y, Festy B. Contribution des principales sources en métaux et métalloïdes à la pollution particulaire de l'agglomération Parisienne. Pollut Atmos Juillet-Septembre 1993:75-88.

Tomassone R, Dervin C, Masson JP. Biométrie, modélisation des phénomènes biologiques. Paris: Masson, 1993:553.
Ulrich E, Williot B. Les dépôts atmosphériques en France de 1850 à 1990. ONF-ADEME eds, ISBN-2 904384 48-0, 1993:154.

Van Daalen J. Air quality and deposition of trace elements in the province of South-Holland. Atmos Environ 1991; 25A(3/4):691-698. 